УДК 378.096

DOI https://doi.org/10.32782/humanitas/2021.6.11

\title{
Оксана ТАШКІНОВА
}

кандидат соиіологічних наук, доцент, завідувачка кафедри соиіології та сочіальної роботи, ДВНЗ «Приазовський державний технічний університет», вул. Університетська, 7, м. Маріуполь, Донечька область, Україна, 87500

ORCID: 0000-0002-6649-845X

\section{Ірина МАРЧЕНКО}

кандидат технічних наук, доцент, декан соиіально-гуманітарного факультету, ДВНЗ «Приазовський державний технічний університет», вул. Університетська, 7, м. Маріуполь, Донеиька область, Україна, 87500

\section{Слизавета БОЙкО}

здобувачка другого (магістерського) рівня вищої освіти, ДВНЗ «Приазовський держсавний технічний університет», вул. Університетська, 7, м. Маріуполь, Донецька область, Україна, 87500

ORCID: 0000-0001-6383-7412

Бібліографічний опис статті: Ташкінова, О., Марченко, І., Бойко, С. (2021). Напрямки розвитку кафедр закладів вищої освіти України, що є випусковими для спеціальності 231 «Соціальна робота». Ввічливість. Humanitas, 6, 75-82, doi: https://doi.org/10.32782/humanitas/2021.6.11

\section{НАПРЯМИ РОЗВИТКУ КАФЕДР ЗАКЛАДІВ ВИЩОЇ ОСВІТИ УКРАЇНИ, ЩО Є ВИПУСКОВИМИ ДЛЯ СПЕЦАЛЬНОСТІ 231 «СОЦАЛЬНА РОБОТА»}

У статті розглядається проблема підвищення якості вищої освіти через розроблення стратегї̈ розвитку кафедри закладу вищої освіти в Украӥні, щчо є випусковою для спеціальності 231 «Соціальна робота». Визначено, шьо модернізація закладів вищої освіти є складним завданням сучасності та вимагає комплексного погляду на трансформаційні процеси, а разом із тим - конкретних дій за різними напрямами. Важливу увагу приділено аналізу застосування ресурсного підходу, згідно з яким для визначення напрямів розвитку випускової кафедри як структурного підрозділу ЗВО варто виділити ресурси, які можуть бути використані для подолання актуальних проблем, а також визначити можливості, які можуть бути використані ЗВО у подальшому. Серед найбільш значущих напрямів визначені такі: навчання, викладання, діяльність наукового товариства студентів, волонтерська служба, працевлаштування студентів, інформащійна діяльність закладу та кафедри, діяльність студентської соиіально-психологічної служби. Всі иі аспекти розглянуто з погляду активного залучення головних стейкхолдерів навчального процесу - гаранта ОП та менеджменту закладу вищої освіти, науково-педагогічних працівників, здобувачів, випускників, зовнішніх партнерів (роботодавців, експертів, практиків), стосунки з якими є стійкими та постійними. Тісна взаємодія між ичии ключовими стейкхолдерами є важливою умовою розвитку ЗВО та освітньої програми, яка реалізується. Крім того, звертається увага на активізачію здобувачів вищої освіти як важливих учасників внутрішньої системи забезпечення якості вищої освіти: починаючи від інформування про можливості участі у ичи прочесах $і$ завершуючи створенням окремих підрозділів (волонтерської служби, студентської сочіально-психологічної служби) за участю студентів. Окрема увага приділена проблемі запровадження міждисциплінарних освітніх (наукових) програм для підготовки майбутніх фахівців із соціальної роботи із розширеними професійними компетентностями на межі декількох галузей знань, спеціальностей.

Ключові слова: соціальна робота, фахівиі/фахівчині сочіальної роботи, якість вищої освіти, стейкхолдери, випускники, заклад вищої освіти, волонтерство.

\section{Oksana TASHKINOVA}

PhD, Associate Professor, Head of the Department of Sociology and Social Work, Pryazovskyi State Technical University, 7 Universitetska str., Mariupol, Donetsk region, Ukraine, 87555

ORCID: 0000-0002-6649-845X 


\section{Iryna MARCHENKO}

PhD, Associate Professor, Dean of Social and Humanitarian Faculty, Pryazovskyi State Technical University, 7 Universitetska str., Mariupol, Donetsk region, Ukraine, 87555

\section{Elizabeth BOYKO}

Student, Specialty Social Work, Pryazovskyi State Technical University, 7 Universitetska str., Mariupol, Donetsk region, Ukraine, 87555

ORCID: 0000-0001-6383-7412

To cite this article: Tashkinova, O., Marchenko, I., Boyko, E. (2021) Napriamky rozvytku kafedr zakladiv vyshchoi osvity Ukrainy, shcho ye vypuskovymy dlia spetsialnosti 231 «Sotsialna robota» [Areas of development of departments of higher education institutions of Ukraine, which are graduates of the specialty 231 "Social Work"]. Vvichlyvist. Humanitas, 6, 75-82, doi: https://doi.org/10.32782/humanitas/2021.6.11

\section{AREAS OF DEVELOPMENT OF DEPARTMENTS OF HIGHER EDUCATION INSTITUTIONS OF UKRAINE, WHICH ARE GRADUATES OF THE SPECIALTY 231 "SOCIAL WORK"}

The article considers the problem of improving the quality of higher education through the development of a strategy for the development of the department of higher education in Ukraine, which is a graduation for the specialty 231 Social Work. It is determined that the modernization of higher education institutions is a complex task of today and requires a comprehensive view of the transformation process, but at the same time specific actions in various areas. Important attention is paid to the analysis of the resource approach, according to which to determine the development of the graduating department as a structural unit of free economic resources, it is necessary to identify resources that can be used to overcome current problems, and identify opportunities that can be used in the future. Among the most important areas are the following: education, teaching, activities of the scientific society of students, volunteer service, employment of students, information activities of the institution and department, the activities of the student's social and psychological service. All these aspects are considered in terms of active involvement of the main stakeholders of the educational process - the guarantor of OP and management of higher education, research and teaching staff, applicants, graduates, external partners (employers, experts, practitioners), with whom relations are stable and permanent. Close cooperation between these key stakeholders is an important condition for the development of free economic education and the educational program that is being implemented. In addition, attention is paid to the activation of higher education as important participants in the internal quality assurance system of higher education: from informing about opportunities to participate in these processes and ending with the creation of separate units (volunteer service, student socio-psychological service) with students. Particular attention is paid to the problem of introducing interdisciplinary educational (scientific) programs for the training of future specialists in social work with expanded professional competencies on the border of several fields of knowledge, specialties.

Key words: social work, social work specialists, quality of higher education, stakeholders, graduates, higher education institution, volunteering.

Актуальність проблеми. Інтеграція вищої освіти в європейський простір та створення Національного агентства із забезпечення якості вищої освіти в Україні надали новий поштовх для покращення якості вищої освіти в Україні на засадах дотримання європейських стандартів. Вища освіта почала розвиватися у напрямі автономності закладів вищої освіти, творчої самоврядності, прозорості, студентоцентрованості та практикоорієнтованості навчання. Трансформація закладів вищої освіти у «самоврядні академічні спільноти» надає нові можливості для розвитку та модернізації, водночас потребує відповідальності та творчого погляду на внутрішні і зовнішні процеси забезпечення якості вищої освіти (М. Винницький, 2020). Підгрунтям для такої трансформації має бути усвідомлення основними стейкхолдерами значення якості освіти, а також ролі і місця закладу у системі трансформацій України загалом.

Модернізація закладів вищої освіти неодмінно поєднується із переглядом наявних освітніх програм (далі - ОП), їхнім удосконаленням та більш широким поглядом на підготовку фахівців за певною спеціальністю. Одним iз напрямів такої трансформації є впровадження міждисциплінарних освітніх програм, підготовка за якими передбачає поєднання кількох спеціальностей у площині однієї або декількох галузей знань. Модернізація закладів вищої 
освіти є складним завданням та вимагає комплексного погляду на трансформаційні процеси, а також конкретних дій за різними напрямами (навчання, викладання тощо). У зв'язку з цим метою статті $є$ спроба об'єднати актуальні трансформаційні процеси за різними складовими напрямами навчальної діяльності у єдину стратегію розвитку спеціальних кафедр закладів вищої освіти, що $є$ випусковими для освітніх програм у межах спеціальності 231 «Соціальна робота».

Аналіз діяльності 3ВО України, стандартів і рекомендацій щодо забезпечення якості в Свропейському просторі вищої освіти (Стандарти і рекомендації щодо забезпечення якості в Європейському просторі вищої освіти, 2015), чинних положень, рекомендацій Національного агентства із забезпечення якості вищої освіти (Сайт Національного агентства із забезпечення якості вищої освіти, 2021) дає можливість окреслити такі актуальні тенденції у розвитку закладів вищої освіти та конкретних ОП:

- відкритість інформації та діяльності ЗВО для всіх зацікавлених осіб (надання повної та правдивої інформації на офіційному сайті університету та сторінках соціальних мереж, створення чат-ботів, каналів у Telegram, проведення відкритих лекцій, занять, профорієнтаційних заходів тощо);

- адаптивність - швидке реагування (вчасне реагування на виклики сьогодення, використання наявних можливостей, ресурсів та пошук нових, переведення проблеми у площину можливостей тощо);

- партнерство - взаємодія на всеукраїнському та міжнародному (інтернаціоналізація) рівні (співпраця, підписання меморандумів, проведення спільних круглих столів, конференцій, форумів на рівні України із залученням іноземних партнерів, обмін досвідом, стажування тощо);

- пошук нових шляхів отримання знань (неформальна та інформальна освіта, обмін досвідом, проведення дуальних лекцій, лекції професіоналів-практиків, виїзні заняття, тренінги, онлайн-курси тощо);

- комплексна підтримка здобувачів та науково-педагогічних працівників (створення волонтерських служб, центрів кар'єри, студентських соціально-психологічних служб, розширення ролі студентського самовряду- вання, функціонування центрів підвищення кваліфікації, професійного розвитку, супервізії тощо);

- створення бренду як чинник успіху та унікальності (створення та постійне використання емблем, окреслення цінностей, діяльності, кар'єрні шляхи та досягнення співробітників і стейкхолдерів, проведення відкритих заходів, постійна комунікація з аудиторією через систематичне оновлення інформації на офіційному веб-сайті, сторінок у соціальних мережах, проведення профорієнтаційних та рекламних компаній тощо).

Отже, трансформаційні напрями є різновекторними, однак їх об'єднує відкритість комунікації та інформації, партнерство і підтримка на противагу конкуренції й одноосібності. Постійна комунікація та взаємодія потребує внутрішньої стабільності та впевненості у стійкому функціонуванні i конкурентоспроможності, можливості вирішувати складні завдання та бути адаптивними до мінливих умов. Такі категорії вимагають творчого підходу, постійної рефлексії та міцного підгрунтя, яке формується 3 мотивації і активності головних стейкхолдерів навчального процесу - НПП, здобувачів, адміністративного персоналу і зовнішніх партнерів, стосунки 3 якими є стійкими та постійними. Тісна взаємодія між цими ключовими стейкхолдерами $є$ наріжним каменем розвитку, однак будь-який суб'єкт потребує підтримки, тобто, маючи проблему і вразливість, має підтримку зі сторони, що допомагає йому впоратися з ситуацією. У такому разі ЗВО повинні дбати про працівників та здобувачів, бо саме це $\epsilon$ характеристикою успішних та продуктивних компаній.

Проблеми з погляду ресурсної моделі можна розглядати як ресурси, можливості для подальшого вдосконалення. Наприклад, проблеми здобувачів вищої освіти можна розподілити за сферами: психологічні (стреси, втрата мотивації до навчання, порушення та психічні розлади); соціальні (проблеми в сім'ї або у взаємодії з оточенням, порушення адаптації, складні життєві обставини); фізіологічні (проблеми зі здоров'ям, інвалідність); економічні (брак коштів на навчання, проживання); навчальні (когнітивні) (погане засвоєння матеріалу, нерозуміння дисциплін).

Згідно 3 таким розподілом, варто виділити ресурси, які можуть бути використані 
для подолання таких проблем, а також можливості, які можуть бути використані ЗВО у подальшому:

- економічні (кошти ЗВО, гранти) - створення соціального проєкту допоможе вирішити складну ситуацію не лише конкретної людини, але й соціальної групи (наприклад, створення соціально-психологічної служби, яка буде допомагати студентам, що перебувають у СЖО або відносяться до вразливої групи), а залучення додаткового фінансування може допомогти покращити зовнішні зв'язки та благоустрій закладу;

- соціальні (соціальні зв'язки, контакти, взаємодія з партнери) - для вирішення проблем можуть потребуватися ресурси зовнішніх партнерів, подальша взаємодія з якими може бути корисною та ресурсною для обох сторін;

- психологічні (мотивація, саморозвиток, саморефлексія) - залучення зовнішніх партнерів може стати поштовхом для саморефлексії, а у подальшому мотивувати для інноваційних перетворень;

- людські (студенти, викладачі, менеджмент 3ВО) - вирішення проблем допоможе згуртувати колектив, проявити сильні сторони учасників, мотивувати до розвитку.
У цьому разі всі ресурси переплітаються між собою, формуючи одну систему, тому соціальні ресурси та людські ресурси виконують ту саму функцію, але 3 різницею в тому, що під соціальними розуміються зовнішні партнери, взаємодія з якими відбувається на регулярній або тимчасовій основі, а людські ресурси відображають постійних активних учасників навчального процесу (здобувачі ВО, викладачі, адміністративний персонал) залежно від включеності у процеси конкретного підрозділу.

Для розкриття змісту напрямів розвитку спеціальних кафедр закладів вищої освіти, що $\epsilon$ випусковими для освітніх програм у межах спеціальності 231 «Соціальна робота», варто більш докладно зупинитися на аналізі таких аспектів, як: навчання, викладання, діяльність наукового товариства студентів, волонтерська служба, працевлаштування студентів, інформаційна діяльність закладу та кафедри, діяльність студентської соціально-психологічної служби.

Напрями покращення діяльності спеціальних кафедр 3ВО, що є випусковими для освітніх програм у межах спеціальності 231 «Соціальна робота»:

\begin{tabular}{|c|c|c|c|}
\hline напрями & складники & стейкхолдери & зміст діяльності \\
\hline 1 & 2 & 3 & 4 \\
\hline \multirow{4}{*}{$\begin{array}{l}\text { якість освітньої } \\
\text { діяльності }\end{array}$} & $\begin{array}{l}\text { розроблення / } \\
\text { моніторинг, } \\
\text { перегляд / } \\
\text { оновлення ОП }\end{array}$ & $\begin{array}{l}\text { гарант ОП, НПП, } \\
\text { здобувачі, соціальні } \\
\text { партнери, експерти, } \\
\text { наукове товариство }\end{array}$ & $\begin{array}{l}\text { системна робота щодо включення } \\
\text { усіх зацікавлених осіб до процедур } \\
\text { розроблення, перегляду і вдосконалення } \\
\text { ОП, проведення соціологічних досліджень } \\
\text { щодо з'ясування думки стейкхолдерів } \\
\text { щодо якості ОП } \\
\end{array}$ \\
\hline & академічна доброчесність & $\begin{array}{l}\text { наукове товариство із } \\
\text { залученням викладачів } \\
\text { та допоміжного } \\
\text { персоналу 3ВО }\end{array}$ & $\begin{array}{l}\text { проведення інформаційних заходів } \\
\text { теоретичного та практичного характеру }\end{array}$ \\
\hline & $\begin{array}{l}\text { індивідуальна освітня } \\
\text { траєкторія студентів }\end{array}$ & $\begin{array}{l}\text { завідувач кафедри, } \\
\text { гарант ОП, викладачі, } \\
\text { менеджмент 3ВО, } \\
\text { студенти }\end{array}$ & $\begin{array}{l}\text { запровадження дієвої та зрозумілої } \\
\text { процедури вибору освітніх компонентів } \\
\text { (ОК) у ЗВО }\end{array}$ \\
\hline & $\begin{array}{l}\text { неформальна } \\
\text { та інформальна } \\
\text { освіта }\end{array}$ & $\begin{array}{l}\text { завідувач кафедри, } \\
\text { викладачі, наукове } \\
\text { товариство }\end{array}$ & $\begin{array}{l}\text { створення можливостей для студентів } \\
\text { щодо неформальної освіти, інформування } \\
\text { про шляхи одержання таких знань, у тому } \\
\text { числі через запровадження ОК «Основи } \\
\text { самоосвіти» }\end{array}$ \\
\hline \multirow[b]{2}{*}{ викладання } & $\begin{array}{l}\text { викладацька } \\
\text { майстерність НПП }\end{array}$ & $\begin{array}{l}\text { Гарант ОП, НПП, } \\
\text { менеджмент ЗВО }\end{array}$ & $\begin{array}{l}\text { Створення можливостей для підвищення } \\
\text { викладацької майстерності НПП через } \\
\text { курси підвищення кваліфікації, участь } \\
\text { у майстер-класах, тренінгах тощо }\end{array}$ \\
\hline & $\begin{array}{l}\text { проведення занять } \\
\text { у соціальних установах, } \\
\text { залучення професіоналів } \\
\text { практиків до викладання } \\
\text { ОК }\end{array}$ & $\begin{array}{l}\text { викладачі, працівники } \\
\text { соціальних } \\
\text { установ-партнерів, } \\
\text { професіонали } \\
\text { практики }\end{array}$ & $\begin{array}{l}\text { попереднє планування проведення } \\
\text { занять залежно від тем та можливостей } \\
\text { соціальних установ, співпраця } \\
\text { та проведення заходів }\end{array}$ \\
\hline
\end{tabular}


Продовження таблиці

\begin{tabular}{|c|c|c|c|}
\hline 1 & 2 & 3 & 4 \\
\hline & $\begin{array}{l}\text { формування додаткових } \\
\text { професійних } \\
\text { компетентностей та soft } \\
\text { skills у здобувачів } \\
\end{array}$ & $\begin{array}{l}\text { викладачі, наукове } \\
\text { товариство, залучені } \\
\text { фахівці }\end{array}$ & $\begin{array}{l}\text { аналіз потреб та зацікавленості студентів, } \\
\text { планування та проведення додаткових } \\
\text { занять, тренінгів, майстер-класів, } \\
\text { зустрічей; }\end{array}$ \\
\hline & \begin{tabular}{|l} 
проведення заходів \\
щодо вдосконалення \\
навичок використання \\
iнформаційних \\
технологій \\
\end{tabular} & $\begin{array}{l}\text { адміністрація закладу, } \\
\text { завідувач кафедри, } \\
\text { залучені фахівці }\end{array}$ & $\begin{array}{l}\text { проведення інформаційних та практичних } \\
\text { заходів для набуття навичок використання } \\
\text { веб-ресурсів. }\end{array}$ \\
\hline & практикоорієнтованість & $\begin{array}{l}\text { адміністрація закладу, } \\
\text { завідувач кафедри, } \\
\text { залучені фахівці }\end{array}$ & $\begin{array}{l}\text { врахування сучасних тенденцій } \\
\text { розвитку спеціальності, запровадження } \\
\text { інноваційних методів та технологій } \\
\text { соціальної роботи }\end{array}$ \\
\hline \multirow{2}{*}{$\begin{array}{l}\text { інформаційна } \\
\text { діяльність закладу } \\
\text { та кафедри }\end{array}$} & $\begin{array}{l}\text { ведення сторінок } \\
\text { у соціальних мережах }\end{array}$ & відповідальна особа & $\begin{array}{l}\text { ведення сторінок у соціальних мережах } \\
\text { (Instagram, Facebook, Telegram), додер- } \\
\text { жання принципу відкритості інформації } \\
\text { щодо різних напрямів діяльності } \\
\end{array}$ \\
\hline & $\begin{array}{l}\text { створення єдиного } \\
\text { каналу комунікації } \\
\text { та обміну інформацією }\end{array}$ & $\begin{array}{l}\text { відповідальна особа } \\
\text { з залученням всіх } \\
\text { зацікавлених осіб }\end{array}$ & $\begin{array}{l}\text { створення каналу в Telegram для швидкого } \\
\text { обміну інформацією, цікавими ідеями, } \\
\text { заходами, уникаючи «застарілості») } \\
\text { та «прихованості» інформації (або } \\
\text { розвиток уже існуючих сторінок) } \\
\end{array}$ \\
\hline \multirow{3}{*}{$\begin{array}{l}\text { працевлашту- } \\
\text { вання студентів }\end{array}$} & $\begin{array}{l}\text { підвищення рівня } \\
\text { конкурентоспроможності } \\
\text { майбутніх випускників } \\
\text { ЗВО на ринку праці }\end{array}$ & $\begin{array}{l}\text { відповідальна особа } \\
\text { з боку кафедри } \\
\text { iз залученням } \\
\text { представників } \\
\text { Служби зайнятості, } \\
\text { структурний підрозділ } \\
\text { 3ВО або відповідальна } \\
\text { особа } \\
\end{array}$ & $\begin{array}{l}\text { проведення інформаційних чи тренінгових } \\
\text { заходів щодо пошуку роботи, написання } \\
\text { резюме, проходження співбесіди, } \\
\text { самопрезентації, створення професійного } \\
\text { іміджу майбутнього фахівця/фахівчині } \\
\text { соціальної роботи }\end{array}$ \\
\hline & $\begin{array}{l}\text { можливості для } \\
\text { працевлаштування } \\
\text { фахівців соціальної } \\
\text { роботи (ФСР) }\end{array}$ & $\begin{array}{l}\text { відповідальна особа } \\
\text { з боку кафедри } \\
\text { з залученням } \\
\text { представників } \\
\text { соціальних установ } \\
\text { (інформаційна } \\
\text { взаємодія) } \\
\end{array}$ & $\begin{array}{l}\text { інформаційна робота щодо окреслення } \\
\text { можливостей для працевлаштування } \\
\text { майбутніх ФСР }\end{array}$ \\
\hline & $\begin{array}{l}\text { поєднання навчання } \\
\text { та роботи, база вакансій } \\
\text { та установ, індивідуальні } \\
\text { плани навчання }\end{array}$ & $\begin{array}{l}\text { відповідальна особа } \\
\text { з боку кафедри } \\
\text { iз залученням } \\
\text { завідувача кафедри, } \\
\text { представників } \\
\text { Служби зайнятості, } \\
\text { міжнародного } \\
\text { відділу, студентського } \\
\text { профкому, соціальних } \\
\text { установ } \\
\end{array}$ & $\begin{array}{l}\text { інформаційна робота щодо можливості } \\
\text { поєднання навчання та роботи, } \\
\text { стажування за кордоном, формування } \\
\text { індивідуального навчального плану, } \\
\text { створення бази вакансій / установ, що } \\
\text { надають вакансії, у тому числі неповної / } \\
\text { вторинної зайнятості }\end{array}$ \\
\hline \multirow{3}{*}{$\begin{array}{l}\text { діяльність наукового } \\
\text { товариства студентів } \\
\text { (НT) }\end{array}$} & $\begin{array}{l}\text { внутрішнє забезпечення } \\
\text { якості ВО }\end{array}$ & $\begin{array}{l}\text { НТ із залученням } \\
\text { завідувача кафедри, } \\
\text { викладачів }\end{array}$ & $\begin{array}{l}\text { проведення інформаційних заходів } \\
\text { теоретичного та практичного характеру: } \\
\text { види плагіату, важливість, правила } \\
\text { формування переліку літератури тощо; } \\
\text { проведення опитування здобувачів щодо } \\
\text { якості ВО, інформування здобувачів про їх } \\
\text { роль у забезпеченні якості ВО } \\
\end{array}$ \\
\hline & $\begin{array}{l}\text { актуалізація науково- } \\
\text { дослідної роботи серед } \\
\text { здобувачів ВО } \\
\end{array}$ & $\begin{array}{l}\text { НТ із залученням } \\
\text { викладачів, персоналу } \\
\text { 3ВО - бібліотеки } \\
\end{array}$ & $\begin{array}{l}\text { проведення інформаційних та практичних } \\
\text { заходів }\end{array}$ \\
\hline & $\begin{array}{l}\text { інформаційна робота, } \\
\text { формування наукового } \\
\text { осередка }\end{array}$ & $\begin{array}{l}\text { НТ із залученням } \\
\text { студентів }\end{array}$ & $\begin{array}{l}\text { ведення сторінок у соціальних мережах, } \\
\text { взаємодія з головною сторінкою кафедри } \\
\text { та менеджером цієї сторінки, інформування } \\
\text { щодо наукових заходів різного рівня } \\
\text { (кафедральних, університетських, } \\
\text { всеукраїнських, міжнародних), } \\
\text { інформування щодо діяльності НПП }\end{array}$ \\
\hline
\end{tabular}


Продовження таблиці

\begin{tabular}{|c|c|c|c|}
\hline 1 & 2 & 3 & 4 \\
\hline & $\begin{array}{l}\text { наукові конференції, } \\
\text { публікація статей, } \\
\text { конкурсні роботи, участь } \\
\text { у інших наукових заходах }\end{array}$ & $\begin{array}{l}\text { НТ із залученням } \\
\text { відповідальних } \\
\text { осіб - за науковими } \\
\text { напрямами }\end{array}$ & $\begin{array}{l}\text { включає елементи двох попередніх блоків } \\
\text { (допомога у написанні та інформаційна } \\
\text { робота), головний аспект - вчасне } \\
\text { iнформування здобувачів щодо наукових } \\
\text { заходів, а також участь в організації } \\
\text { наукових заходів кафедри та ЗВО }\end{array}$ \\
\hline \multirow{3}{*}{$\begin{array}{l}\text { навчальна практика } \\
\text { та створення } \\
\text { волонтерської } \\
\text { служби }\end{array}$} & $\begin{array}{l}\text { якісна практична } \\
\text { підготовка майбутніх } \\
\text { ФСР }\end{array}$ & $\begin{array}{l}\text { гарант ОП, } \\
\text { відповідальний } \\
\text { за організацію } \\
\text { та проведення } \\
\text { практики, соціальні } \\
\text { партнери - } \\
\text { роботодавці, здобувачі } \\
\end{array}$ & $\begin{array}{l}\text { організація та здійснення скрізної } \\
\text { практичної підготовки майбутніх ФСР } \\
\text { починаючи з другого семестру навчання. }\end{array}$ \\
\hline & $\begin{array}{l}\text { заходи щодо } \\
\text { залучення студентів } \\
\text { до волонтерства / } \\
\text { волонтерської практики; } \\
\text { створення волонтерської } \\
\text { служби }\end{array}$ & $\begin{array}{l}\text { студентський } \\
\text { координатор } \\
\text { волонтерської } \\
\text { діяльності, } \\
\text { відповідальна особа } \\
\text { з числа викладачів } \\
\text { кафедри } \\
\end{array}$ & $\begin{array}{l}\text { - інформаційні заходи щодо залучення } \\
\text { студентів до волонтерської діяльності, } \\
\text { ознайомлення з базами практик; } \\
\text { - інформаційні та тренінгові заходи щодо } \\
\text { підтримки мотивації у студентів займатись } \\
\text { волонтерською діяльності, запровадження } \\
\text { мотиваційних бонусів }\end{array}$ \\
\hline & $\begin{array}{l}\text { координація діяльності, } \\
\text { проведення підсумкового } \\
\text { круглого столу }\end{array}$ & $\begin{array}{l}\text { студентські } \\
\text { координатори баз } \\
\text { практик, студентський } \\
\text { координатор } \\
\text { волонтерської } \\
\text { діяльності, } \\
\text { відповідальна особа } \\
\text { з числа викладачів } \\
\text { кафедри, представники } \\
\text { волонтерських баз } \\
\text { практик } \\
\end{array}$ & $\begin{array}{l}\text { взаємодія між студентськими } \\
\text { координаторами баз практик, } \\
\text { студентським координатором } \\
\text { волонтерської діяльності та відповідальної } \\
\text { особи з числа викладачів кафедри, } \\
\text { підтримка волонтерів, вдосконалення } \\
\text { партнерства, проведення підсумкового } \\
\text { круглого столу }\end{array}$ \\
\hline \multirow{3}{*}{$\begin{array}{l}\text { діяльність } \\
\text { студентської } \\
\text { соціально- } \\
\text { психологічної } \\
\text { служби }\end{array}$} & $\begin{array}{l}\text { організація } \\
\text { та проведення соціально- } \\
\text { профілактичних, } \\
\text { психологічних } \\
\text { і соціальних заходів } \\
\text { та реалізація соціальних } \\
\text { проєктів } \\
\end{array}$ & $\begin{array}{l}\text { відповідальна особа } \\
\text { з числа студентів } \\
\text { та викладачів, } \\
\text { студентським } \\
\text { профкомом, соціальні } \\
\text { організації, волонтери, } \\
\text { залучений фахівець } \\
\end{array}$ & $\begin{array}{l}\text { організація та проведення індивідуальних } \\
\text { та групових консультацій (консультації, } \\
\text { лекції, тренінги), соціальний супровід, } \\
\text { виховна робота }\end{array}$ \\
\hline & $\begin{array}{l}\text { соціальна підтримка } \\
\text { студентів вразливих груп } \\
\text { та таких, що опинились } \\
\text { у СЖО }\end{array}$ & $\begin{array}{l}\text { відповідальна особа } \\
\text { з числа студентів } \\
\text { та викладачів, } \\
\text { закріплені волонтери, } \\
\text { залучений фахівець }\end{array}$ & $\begin{array}{l}\text { проведення індивідуальних консультацій, } \\
\text { соціальний супровід осіб, що цього } \\
\text { потребують, допомога особам, що } \\
\text { опинились у СЖО, та вразливим групам } \\
\text { (ВПО, особи з інвалідністю, молоді сім'ї } \\
\text { тощо); }\end{array}$ \\
\hline & $\begin{array}{l}\text { соціальна адаптація } \\
\text { першокурсників }\end{array}$ & $\begin{array}{l}\text { відповідальна особа } \\
\text { з числа студентів } \\
\text { та викладачів, } \\
\text { залучений фахівець }\end{array}$ & $\begin{array}{l}\text { проведення групових та індивідуальних } \\
\text { консультацій, екскурсій, семінарів, } \\
\text { щодо структури закладу, посвяти для } \\
\text { першокурсників тощо }\end{array}$ \\
\hline
\end{tabular}

Важливим напрямом розвитку кафедр закладів вищої освіти, що є випусковими для спеціальності 231 «Соціальна робота», може стати запровадження міждисциплінарних освітніх програм. Міждисциплінарна освітня програма передбачає поєднання підготовки за кількома спеціальностями у площині однієї або декількох галузей знань залежно від рівня освіти. Міждисциплінарні освітні (наукові) програми активно впроваджують прогресивні країни Європейського простору вищої освіти. Розвиток таких програм в Україні відкриє нові професійні та академічні права майбутнім фахівцям та сприятиме підвищенню конкурентоспроможності національної системи вищої освіти загалом (Про затвердження Вимог до міждисциплінарних освітніх (наукових) програм, 2021).

Освітня (наукова) програма вважається міждисциплінарною, якщо обсяг освітніх компонентів у кредитах європейської кредитної трансферно-накопичувальної системи, що може бути співвіднесений з відповідними спеціальностями (галузями), які визначають 
ii предметну сферу, є приблизно однаковий. У разі домінування одного з таких компонентів програму слід віднести саме до відповідної спеціальності (галузі), а не вважати міждисциплінарною. У лютому 2021 року було видано Наказ Міністерства освіти і науки України №128 «Про затвердження Вимог до міждисциплінарних освітніх (наукових) програм» (Про затвердження Вимог до міждисциплінарних освітніх (наукових) програм, 2021). Вимоги цього наказу поширюються на освітньо-наукові програми рівня молодшого бакалавра, магістра та доктора філософії.

Міждисциплінарна освітня (наукова) програма передбачає опанування знання, що знаходиться на межі галузей знань, спеціальностей та/або належить до кількох спеціальностей, які і визначають іiі предметну сферу. Інформація про відповідні галузі, спеціальності зазначається в документі про здобуту вищу освіту, що видається після успішного завершення програми, як елемент опису освітньої кваліфікації. Зміст міждисциплінарної освітньої програми має відповідати предметній області, визначеної цими галузями, спеціальностями.

Міждисциплінарні освітні (наукові) програми можуть створюватись із залученням до предметної сфери всіх галузей та спеціальностей, крім тих, що входять до Переліку спеціальностей, здобуття ступеня освіти 3 яких необхідне для доступу до професій, для яких запроваджено додаткове регулювання, затвердженого наказом Міністерства освіти і науки України 22 травня 2020 року № 673. Також важливо зазначити, що на першому (бакалаврському) рівні не передбачено можливість розроблення та впровадження міждисциплінарних програм.

Таким чином, сучасна система вищої освіти реалізується в нових умовах, пов'язаних із: змішаним та дистанційним навчанням; новими вимогами до забезпечення якості навчання та викладання у ЗВО, врахуванням запитів та потреб зовнішніх та внутрішніх стейкхолдерів; необхідністю врахування вимог стандартів вищої освіти та професійних стандартів; формуванням загальних та фахових компетентностей у майбутніх фахівців із соціальної роботи iз застосуванням комплексного та збалансованого підходу; міждисциплінарністю підготовки майбутніх ФСР що зумовлено специфікою майбутньої професійної діяльності тощо. Важливо під час розроблення стратегії розвитку кафедри закладу вищої освіти України, що $\epsilon$ випусковою для спеціальності 231 «Соціальна робота», враховувати тенденції розвитку вищої освіти в Україні, а також напрями реформування соціальної сфери і специфіку майбутньої професійної діяльності фахівців із соціальної роботи в Україні.

\section{ЛІТЕРАТУРА:}

1. Про Цілі сталого розвитку України на період до 2030 року : указ президента України. URL: https://zakon.rada.gov.ua/laws/show/722/2019\#Text

2. Сайт Національного агентства із забезпечення якості вищої освіти. URL: https://naqa.gov.ua/

3. Винницький M. Нам не потрібна "вивихнута" автономія. URL: http://surl.li/aebcd

4. Стандарти і рекомендації щодо забезпечення якості в Європейському просторі вищої освіти (ESG). URL: https://cutt.ly/JWgZLeQ

5. Рекомендації щодо застосування критеріїв оцінювання якості освітньої програми Національного агентства із забезпечення якості вищої освіти. URL: https://cutt.ly/jWgZwG1

6. Про вищу освіту : Закон України № 37-38, від 01.08.2021 p. URL: https://cuti.cc/K0hjI

7. Про затвердження Вимог до міждисциплінарних освітніх (наукових) програм : Наказ Міністерства освіти $\mathrm{i}$ науки України №128. URL: https://cutt.ly/kEx4jOy

\section{REFERENCES:}

1. Pro Tsili staloho rozvytku Ukrainy na period do 2030 roku (2019): ukaz prezydenta Ukrainy [On the Goals of Sustainable Development of Ukraine until 2030: Decree of the President of Ukraine]. Retrieved from: https://zakon.rada.gov.ua/laws/show/722/2019\#Text [in Ukrainian].

2. Sait Natsionalnoho ahentstva iz zabezpechennia yakosti vyshchoi osvity (2021) [Website of the National Agency for Quality Assurance in Higher Education]. Retrieved from: https://naqa.gov.ua/ [in Ukrainian].

3. Vynnytskyi , M. (2020). Nam ne potribna "vyvykhnuta" avtonomiia [We do not need "dislocated" autonomy]. Retrieved from: http://surl.li/aebcd [in Ukrainian]. 
4. Standarty i rekomendatsii shchodo zabezpechennia yakosti v Yevropeiskomu prostori vyshchoi osvity (ESG) (2015) [Standards and recommendations for quality assurance in the European Higher Education Area]. Retrieved from: https://cutt.ly/JWgZLeQ [in Ukrainian].

5. Rekomendatsii shchodo zastosuvannia kryteriiv otsiniuvannia yakosti osvitnoi prohramy Natsionalnoho ahentstva iz zabezpechennia yakosti vyshchoi osvity (2020) [Recommendations on the application of criteria for assessing the quality of the educational program of the National Agency for Quality Assurance in Higher Education]. Retrieved from: https://cutt.ly/jWgZwG1 [in Ukrainian].

6. Pro vyshchu osvitu (2021): Zakon Ukrainy № 37-38 [About higher education]. Retrieved from: https://cuti.cc/K0hjI [in Ukrainian].

7. Pro zatverdzhennia Vymoh do mizhdystsyplinarnykh osvitnikh (naukovykh) prohram (2021): Nakaz Ministerstva osvity i nauky Ukrainy №128. [On approval of the Requirements for interdisciplinary educational (scientific) programs]. Retrieved from: https://cutt.ly/kEx4jOy [in Ukrainian]. 